\title{
AN ALTERNATIVE USAGE OF URTICA DIOICA AS ADSORBENT FOR MALACHITE GREEN: OPTIMIZATION STUDY
}

\author{
BENGÜ ERTAN ${ }^{a^{*}}$, SUMEYRA GURKOK ${ }^{\mathrm{b}}$, DERYA EFE ${ }^{\mathrm{a}}$
}

\begin{abstract}
The adsorption of malachite green (MG) by the use of an ecofriendly adsorbent Urtica dioica (U. dioica) has been reported in the present study. The effects of different parameters were tested on MG adsorption and optimization of the effective parameters $(\mathrm{pH}$, temperature and initial dye concentration) were performed by response surface methodology (RSM). Maximal adsorption yield of $91.67 \%$ was achieved at $\mathrm{pH} 6.5$ and $50{ }^{\circ} \mathrm{C}$ with $200 \mathrm{mgL}^{-1}$ initial dye concentration. The isotherm and kinetic studies were employed to describe the adsorption process. The experimental data fitted better on the Freundlich model and the adsorption process followed by the pseudo-second order model.
\end{abstract}

Keywords: Urtica dioica, Malachite Green, Adsorption, Response Surface Methodology

\section{INTRODUCTION}

The environmental pollution is a global problem as a result of rapid industrialization. Waste water discharged into natural water sources is mostly contaminated with synthetic dyes, which are the main water pollutants with an annual production of more than 700,000 tons and more than 10000 varieties. [1]. One of the most hazardous coloring agents is malachite green (MG). It is an organic cationic dye widely used in different industries such as textile, rubber, paper, plastic, leather, cosmetic, food and printing [2,3]. MG is also used as an antimicrobial agent in aquaculture and for staining bacterial endospores and tissue samples. MG is known as a mutagenic and carcinogenic multiorgan toxin causing serious damages in liver, spleen, heart, and lungs. In

\footnotetext{
a Giresun University, Espiye Vocational School, Adabük, 28500/Düzköy, Espiye, Giresun, Turkey

b Ataturk University, Faculty of Science, Department of Biology, 25240, Erzurum, Turkey

*Corresponding author: bengu.ertan@giresun.edu.tr
} 
addition, like other synthetic dyes, the widespread use of MG causes significant environmental problems by preventing sunlight from penetrating into the water, thereby reducing the effectiveness of photosynthesis. $[4,5]$. Since MG is defined as a Class II Health Hazard in the United States, its use in aquaculture is prohibited by the Food and Drug Administration. Serious health problems have been reported in many countries as a result of eating aquatic fish contaminated with MG [6,7]. However, millions of kilograms of MG are still produced annually and are used as dyes due to their low prices, easy availability, effectiveness and lack of a suitable alternative [8].

MG has a complex, stable and non-biodegradable structure, therefore, it should be removed using an effective treatment method before being released into the media [9]. Recently, the adsorption with various adsorbents has gained importance and great demand due to its efficiency and simplicity $[10,11]$. The use of biomaterials for adsorption has many advantages in terms of low cost, efficiency, availability and being environmentally friendly $[12,13]$. Although many studies have been carried out on the adsorption potential of different biomaterials such as oil palm [14], de-oiled soya [15], rice straw [16], corn stalks [13], etc. $[17,18]$, there is still a great interest and demand to evaluate adsorption potential of novel and alternative materials.

$U$. dioica, belonging to Urticaceaea family, is a perennial plant with the ability to grow 2 to 4 meters high $[19,20]$. It has upstanding green stem, opposite and finely toothed leaves with dark green above and paler beneath and dioecious flowers in reddish-brown to greenish-white color [21]. Although it origins from colder region of Northern Europe and Asia, it spreads all over the world especially temperate zones of the world. U. dioica, generally an under storey plant, is called as nettle or stinging nettle because of its stinging hairs on the leaves [22]. It is known as a medical plant because of its antimicrobial, antioxidant, antiulcer, analgesic, antidiabetic, and anticancer properties [23]. Likewise, $U$. dioica has a significant adsorption potential, as it has soft, resistant and low specific weight fibers which possess non-lignified cell walls [24]. In several studies, it has been reported as adsorbent for the heavy metals such as $\mathrm{Cu}, \mathrm{Pb}$, and $\mathrm{Cd}$ [25].

Various factors such as temperature, initial dye concentrations, amount of adsorbent, $\mathrm{pH}$, contact time and particle size of adsorbent determine the efficiency of dye adsorption process. In order to achieve an effective MG adsorption, it is essential to analyze their effects and optimize them. Evaluating these variables individually and finding their optimum values takes a lot of time and ignores the interaction between the parameters. Instead of traditional optimization techniques, statistical techniques [26] have been widely used to improve a wide range of bioprocesses in recent publications $[27,28]$. Statistical approaches, such as response surface methodology (RSM), provide 
comprehensive information about the processes and reduce time and expense by ensuring fewer experiments. RSM is a highly accepted mathematical and statistical technique that is used in determining optimum conditions and clarifying the interactions of the parameters, especially in processes where several parameters affect the response. In order to determine the optimal conditions for maximal yield, RSM creates empirical models and designs experiments. Response surface designs have two basic types, central composite design (CCD) and Box-Behnken design (BBD). BBD has less design points and requires fewer experiments than CCD and therefore, it is less expensive to run with the same number of factors.

Therefore, the present study aimed to determine the adsorption potential of $U$. dioica grown in Giresun and to optimize the operation conditions of MG adsorption. BBD of RSM was applied for analyzing the effects of temperature, $\mathrm{pH}$ and initial dye concentration on $\mathrm{MG}$ adsorption. The use of $U$. dioica for the adsorption of $M G$ and optimization of the operation conditions has been reported for the first time in this study.

\section{RESULTS AND DISCUSSION}

\section{The adsorption parameters of the MG removal}

Several factors are known to affect the adsorption process. Among them, significant variables $(\mathrm{pH}$, initial dye concentration, adsorbent amount, contact time) have been tested in this study.

\section{Effect of $\mathrm{pH}$}

The $\mathrm{pH}$ of the media determines the ionization degree of the adsorbent and the dissociation of functional groups [29]. The effect of $\mathrm{pH}$ was evaluated in the $\mathrm{pH}$ range of $2-8$ as seen from Fig. $1 \mathrm{a}$. At the initial $\mathrm{pH}$, the number of negatively charged groups on the surface of adsorbent was decreased. As the $\mathrm{pH}$ increased, the negatively charged groups on the surface of the adsorbent and MG adsorption increased (max. adsorption $84.88 \%$ at $\mathrm{pH} 6$ ). This can be explained as a result of the electrostatic attraction between positively charged MG molecules and negatively charged $U$. dioica. $\mathrm{pH}$ values above 8 have not been investigated due to the instability of MG color. 

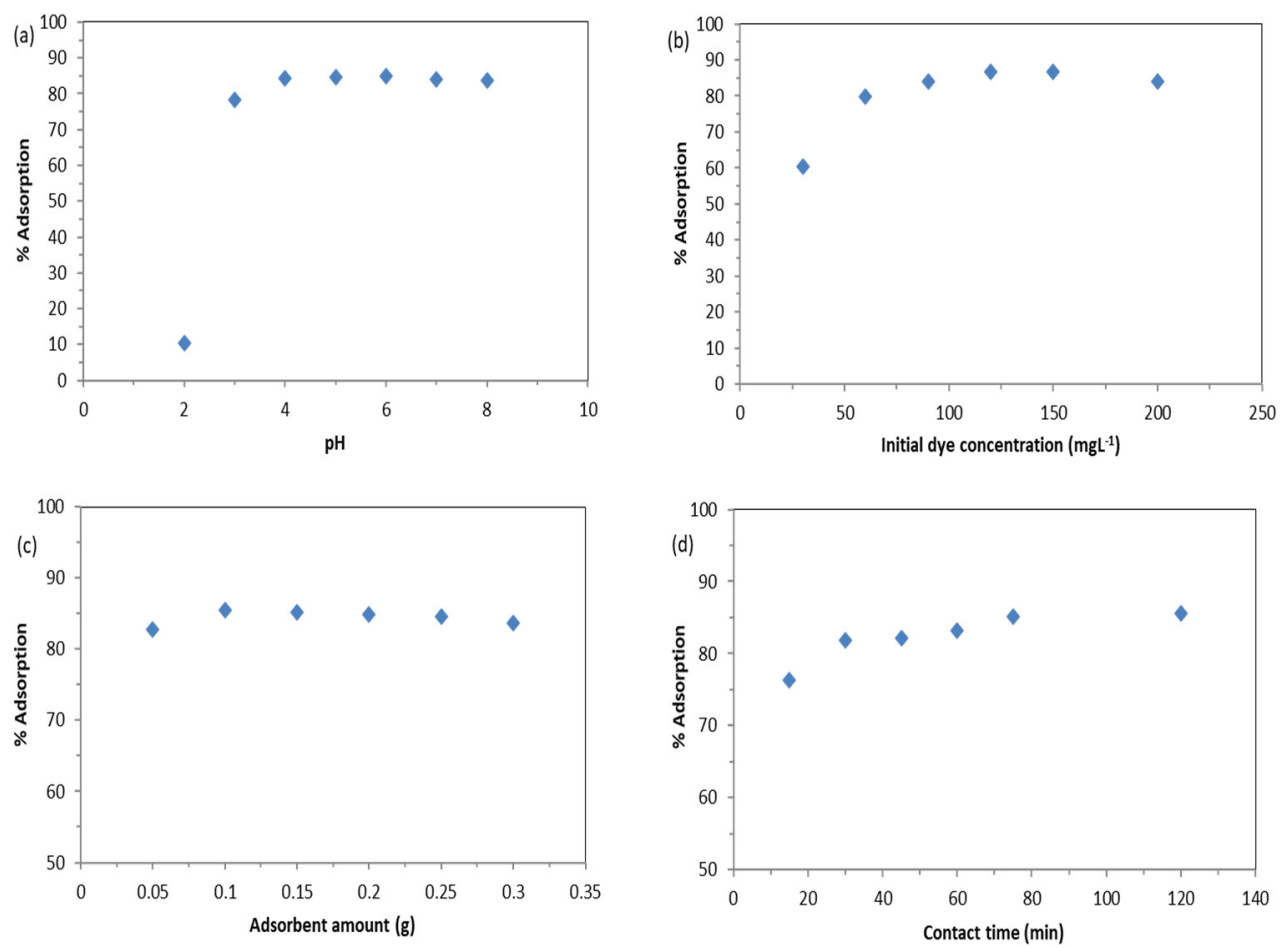

Figure 1. The effect of (a) $\mathrm{pH}\left(150 \mathrm{mgL}^{-1}\right.$ initial dye concentration, $0.1 \mathrm{~g}$ adsorbent amount at room temperature); (b) initial dye concentration ( $\mathrm{pH}: 6,0.1 \mathrm{~g}$ adsorbent amount at room temperature); (c) adsorbent amount (150 $\mathrm{mgL}^{-1}$ initial dye concentration, $\mathrm{pH}: 6$, at room temperature); (d) contact time $\left(150 \mathrm{mgL}^{-1}\right.$ initial dye concentration, $\mathrm{pH}: 6,0.1 \mathrm{~g}$ adsorbent amount at room temperature) on the adsorption of $U$. dioica

\section{Effect of initial dye concentration}

The influence of the initial MG concentration on adsorption was performed at fixed values of $\mathrm{pH}(6)$, adsorbent amount $(0.1 \mathrm{~g})$ and contact time (2 h). As shown in Fig. 1b, adsorption (\%) increased with the increasing initial dye concentration depending on the available binding sites. Adsorption (\%) did not changed above $150 \mathrm{mgL}^{-1}$ of MG concentration as the adsorption sites of the adsorbent were almost completely occupied or reached saturation. 


\section{Effect of adsorbent amount}

Effect of adsorbent amount on the adsorption was studied in the range of $0.05-0.3 \mathrm{~g}$. As the quantity of adsorbent increases, an increase in the number of suitable sites and surface area occurs. Even the use of a small amount of $U$. dioica was effective in MG removal, as seen in Fig. 1c.

\section{Effect of contact time}

In the first $15 \mathrm{~min}$, the adsorption rapidly increased by $77 \%$, then increased more slowly. Equilibrium was reached with an adsorption rate of $85 \%$ in 75 min and this value did not change in the following periods as seen in Fig. 1d [30].

\section{Statistical optimization of dye adsorption conditions by $B B D$ of $R S M$}

The effects of three parameters $\mathrm{pH}$, initial MG concentration and temperature on \% adsorption of $U$. dioica on $M G$ were studied and interactive effects of the variables on the adsorption yields were presented in Fig. 2. Fig. 2a shows the interactive effect of $\mathrm{pH}$ and temperature on the adsorption of MG. According to this figure, adsorption efficiency (\%) increased significantly with increasing $\mathrm{pH}$, but less affected by increasing temperature.

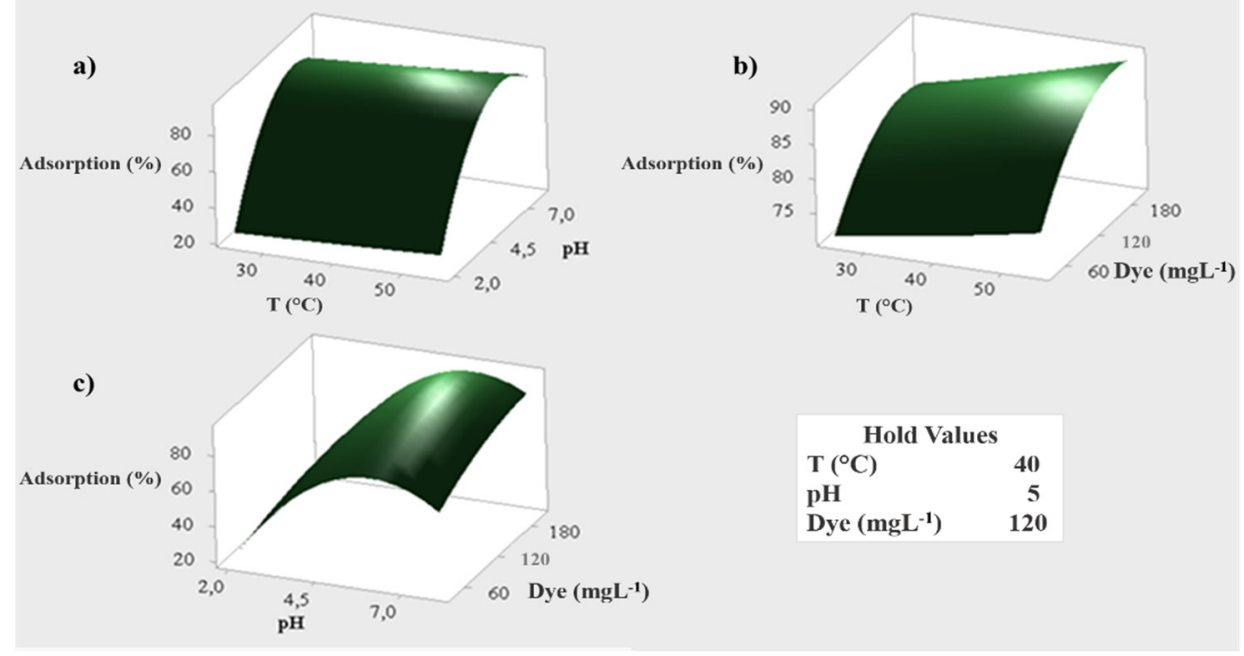

Figure 2. Response surface plots presenting the interactive effects of $\mathrm{pH}$ and temperature (a), initial dye concentration and temperature (b), and initial dye concentration and $\mathrm{pH}$ (c) on MG adsorption. In all cases, the third factor was fixed at the middle point. 
The combined effect of initial dye concentration and temperature is seen in Fig. 2b. Likewise, adsorption efficiency increased with increasing initial MG concentration and temperature, but it can be seen from this figure that initial MG concentration is more effective than temperature. The positive effect of combined initial $\mathrm{MG}$ concentration and $\mathrm{pH}$ on the adsorption yield of $\mathrm{MG}$ is given in Fig. 2c. It is deduced from the figures that the most dominant parameter is $\mathrm{pH}$, then the initial MG concentration and temperature, respectively.

Response surface plots (Fig. 2) and contour plots (Fig. 3) show maximal adsorption efficiency around $80-90 \%$ which was obtained when the temperature, $\mathrm{pH}$, and initial dye concentration reached slightly beyond the $50{ }^{\circ} \mathrm{C}, \mathrm{pH} 6$, and $180 \mathrm{mgL}^{-1}$, respectively.
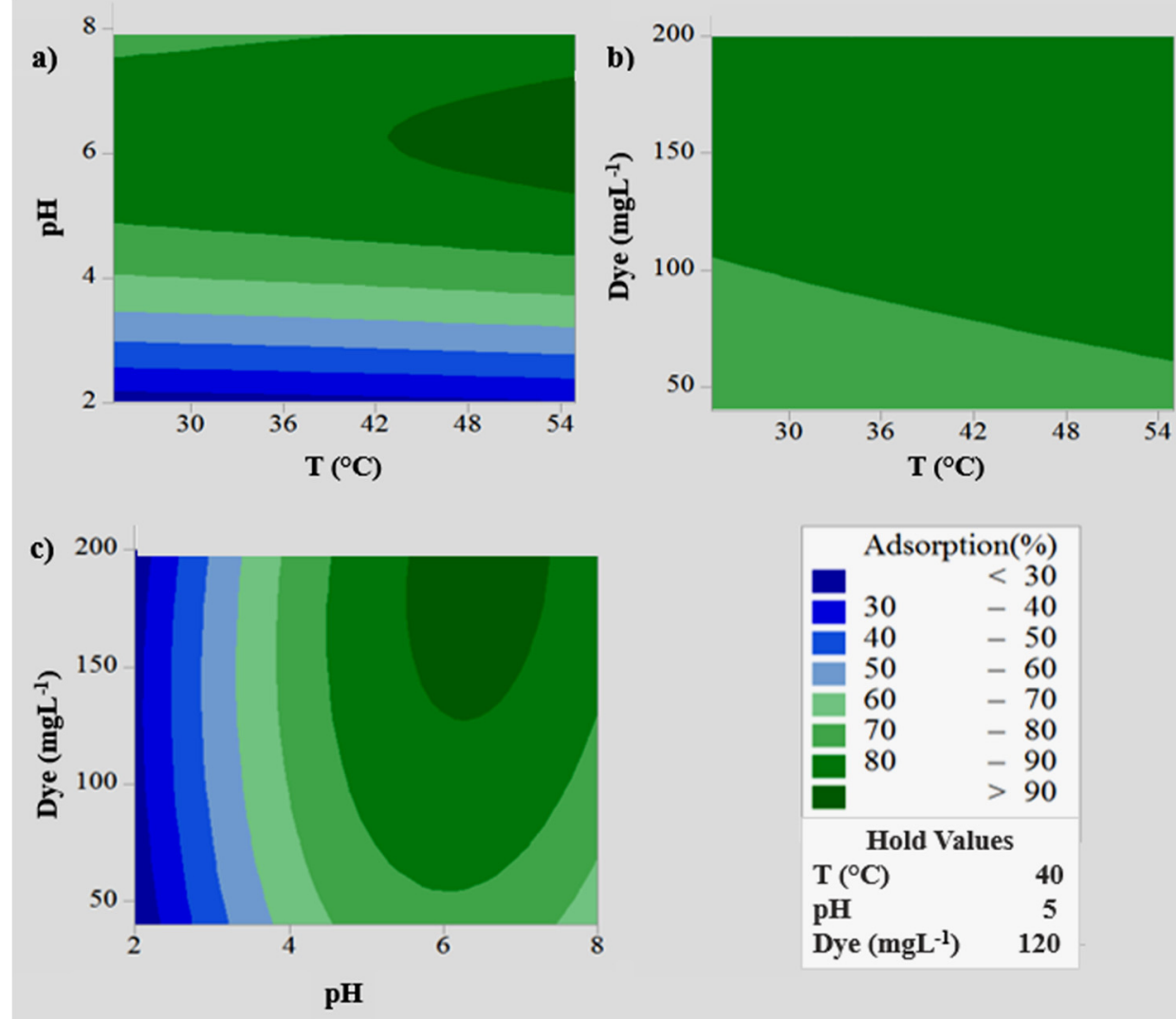

Figure 3. Contour plots presenting the interactive effects of $\mathrm{pH}$ and temperature (a), initial dye concentration and temperature (b), and initial dye concentration and $\mathrm{pH}$ (c) on MG adsorption. In all cases, the third factor was fixed at the middle point. 
The regression analysis for the dye adsorption model is given in Table 1. As it is seen from the regression analysis and also from the surface plots, the temperature is the less effective factor on the adsorption efficiency. When the temperature increased, the efficiency increased slightly. However, increase in $\mathrm{pH}$ and initial dye concentration effectively increased the efficiency. Beyond these levels, increase either caused adverse effect on responses or did not affect.

In Fig. 3, contour plots of $\mathrm{T}^{*} \mathrm{pH}(p: 0.407)$ and $\mathrm{T}^{*}$ Dye concentration $(p: 0.532)$ interactions resulted in orbicular shape, which means there are negligible interaction between the variables. Elliptical shape in contour plot of $\mathrm{pH}^{*}$ Dye concentration $(p<0.0001)$ indicated significant interaction between the variables [27].

Table 1. Predicted coefficients of regression analysis for dye adsorption

\begin{tabular}{|l|l|l|l|l|}
\hline Term & Coef & SE Coef & T-Value & $p$-Value \\
\hline Constant & 83.920 & 1.280 & 65.510 & $p<0.0001$ \\
\hline $\mathrm{A}-\mathrm{T}\left({ }^{\circ} \mathrm{C}\right)$ & 3.096 & 0.785 & 3.950 & 0.001 \\
\hline B-pH & 25.943 & 0.785 & 33.070 & $p<0.0001$ \\
\hline C-Dye $\left(\mathrm{mgL}^{-1}\right)$ & 5.877 & 0.785 & 7.490 & $p<0.0001$ \\
\hline $\mathrm{A}^{2}-\mathrm{T}\left({ }^{\circ} \mathrm{C}\right)^{*} \mathrm{~T}\left({ }^{\circ} \mathrm{C}\right)$ & 0.240 & 1.150 & 0.210 & 0.835 \\
\hline $\mathrm{B}^{2}-\mathrm{pH}{ }^{*} \mathrm{pH}$ & -31.150 & 1.150 & -26.970 & $p<0.0001$ \\
\hline $\mathrm{C}^{2}-\mathrm{Dye}\left(\mathrm{mgL}^{-1}\right)^{*} \mathrm{Dye}\left(\mathrm{mgL}^{-1}\right)$ & -4.470 & 1.150 & -3.870 & 0.001 \\
\hline $\mathrm{AB}-\mathrm{T}\left({ }^{\circ} \mathrm{C}\right)^{*} \mathrm{pH}$ & 0.940 & 1.110 & 0.850 & 0.407 \\
\hline $\mathrm{AC}-\mathrm{T}\left({ }^{\circ} \mathrm{C}\right)^{*} \mathrm{Dye}\left(\mathrm{mgL}^{-1}\right)$ & 0.710 & 1.110 & 0.640 & 0.532 \\
\hline $\mathrm{BC}-\mathrm{pH}^{*} \mathrm{Dye}\left(\mathrm{mgL}^{-1}\right)$ & 4.730 & 1.110 & 4.270 & $p<0.0001$ \\
\hline
\end{tabular}

SE: Standard Error; Coef: Coefficient; T: Student's t-Test; $p$ : Probability

Optimization of adsorption process was performed by applying second order polynomial equation and the generalized polynomial model equation Eq. 1 for three factors was as follows;

$$
Y=b_{0}+b_{1} A+b_{2} B+b_{3} C+b_{11} A^{2}+b_{22} B^{2}+b_{33} C^{2}+b_{12} A B+b_{13} A C+b_{23} B C
$$


In Eq. 1, $\mathrm{Y}$ is the predicted response (adsorption yield), A, B, C are independent variables [(temperature $(A), \mathrm{pH}(B)$ and initial dye concentration $(C)], b_{0}$ is the intercept (constant), $b_{1}, b_{2}, b_{3}$ are linear coefficients, $b_{11}, b_{22}, b_{33}$ are the squared coefficients and $b_{12}, b_{13}, b_{23}$ are the interaction coefficients.

According to the regression analysis, $A, B, C, B^{2}, C^{2}, B C$, are significant terms for the model $(p<0.05)$. Other terms can be considered as insignificant $(p>0.05)$ and deduced from the equation for the improvement of the model. Therefore, the final reduced empirical formula to predict the adsorption yield $(Y)$ is shown as Eq. 2 .

$$
Y=83.92+3.09 A+25.94 B+5.88 C-31.15 B^{2}-4.47 C^{2}+4.73 B C
$$

where $Y$ is predicted response which stands for adsorption yield, $A, B$, and $\mathrm{C}$ stands for coded value of temperature, $\mathrm{pH}$ and initial dye concentration, respectively.

The magnitute of model coefficients in Table 1 indicate that $\mathrm{pH}$ (25.943) had a more prominent effect on adsorption efficiency than initial dye concentration (5.877) and temperature (3.096).

The ANOVA of the quadratic polynomial model for adsorption efficiency was shown in Table 2. The $F$-value of 213.46 and $p$-value of 0.000 verify the model is statistically highly significant. The $p$-value of Lack-of-Fit $(0.882)$ indicates the model successfully predicted the dye adsorption efficiency and the experimental data fitted well on the model. The $R^{2}$ value of 0.99 revealed that the results of the experiments adequately fit to the regression model equation. The predicted $R^{2}$ of 0.97 is in acceptable agreement with the adjusted $\mathrm{R}^{2}$ of 0.98 (Table 2 ).

Table 2. ANOVA of quadratic polynomial model for adsorption efficiency

\begin{tabular}{|l|c|c|c|l|l|}
\hline Source & DF & Adj SS & Adj MS & F-Value & $p$-Value \\
\hline Model & 9 & 18920.1 & 2102.2 & 213.46 & $p<0.0001$ \\
\hline Linear & 3 & 11475.0 & 3825.0 & 388.38 & $p<0.0001$ \\
\hline Square & 3 & 7254.7 & 2418.2 & 245.54 & $p<0.0001$ \\
\hline 2-Way Interaction & 3 & 190.4 & 63.5 & 6.44 & 0.003 \\
\hline Error & 20 & 197.0 & 9.8 & & \\
\hline Lack-of-Fit & 3 & 7.3 & 2.4 & 0.22 & $\mathbf{0 . 8 8 2}$ \\
\hline Pure Error & 17 & 189.6 & 11.2 & & \\
\hline Total & 29 & 19117.1 & & & \\
\hline
\end{tabular}

$R^{2}: 0.99$

$R^{2}($ Adj): 0.98

$R^{2}$ (Pred): 0.97

DF: Degree of freedom; Adj: Adjusted; SS: Sum of squares; MS: Mean square; 
Multiple response prediction for dye adsorption under the optimized condition $\left(50^{\circ} \mathrm{C}, \mathrm{pH} 6.5\right.$ and $200 \mathrm{mgL}^{-1}$ initial dye concentration) determined by MINITAB program was performed in triplicate. Adequate agreement was achieved between the statistically estimated adsorption yield $(90 \%)$ and measured (experimental) adsorption yield (91.67\%).

\section{Adsorption isotherms}

The isotherm models were used to define the equilibrium data and the Freundlich isotherm model had a higher $\mathrm{R}^{2}$ value with 0.9912 than the Langmuir model. In this model, it is suggested that the sorbent has a surface with a nonuniform distribution and the adsorbent surface is heterogeneous [31]. The $n$ value of 0.918 obtained from the Freundlich isotherm showed that the interaction forces between the dyes and adsorbent were strong. The results are presented in Table 3.

Table 3. Isotherm constants for the adsorption of MG onto $U$. dioica

\begin{tabular}{|c|c|c|c|}
\hline Langmuir & $q_{\max }\left(\mathrm{mgg}^{-1}\right)$ & $\mathrm{K}_{\mathrm{L}}\left(\mathrm{Lmg}^{-1}\right)$ & $\mathrm{R}^{2}$ \\
\hline & 24.631 & 0.026 & 0.987 \\
\hline Freundlich & $\mathrm{n}$ & $\mathrm{K}_{\mathrm{F}}\left(\mathrm{Lmg}^{-1}\right)$ & $\mathrm{R}^{2}$ \\
\hline & 0.918 & 2.312 & 0.991 \\
\hline
\end{tabular}

\section{Adsorption kinetics}

Adsorption kinetics were used to test the experimental data, to examine the mechanism of the adsorption process and to predict the adsorption rate quantitatively. The pseudo-first order and the pseudo-second order kinetic models were applied [32]. According to the $\mathrm{R}^{2}$ values in Table 4, The pseudosecond kinetic model was the most ideal to describe adsorption kinetic with the $R^{2}$ value $(0.999)$ and $q_{e}$ value calculated from model $\left(58.823 \mathrm{mgg}^{-1}\right)$ was also very close the experimental $\mathrm{q}_{\mathrm{e}}$ value $\left(56.16 \mathrm{mgg}^{-1}\right)$. It has been elucidated that the rate-limiting step can be chemisorption involving valence forces with sharing or exchange of electrons between adsorbent and dye [33].

Table 4. Kinetic parameters for the adsorption of MG onto $U$. dioica

\begin{tabular}{lccc}
\hline Pseudo-first order kinetic model & $\mathrm{k}_{1}\left(\mathrm{~min}^{-1}\right)$ & $\mathrm{q}_{\mathrm{e}}\left(\mathrm{mgg}^{-1}\right)$ & $\mathrm{R}^{2}$ \\
& 0.205 & 39.415 & 0.966 \\
Pseudo-second order kinetic model & $\mathrm{k}_{2}\left(\mathrm{mgg}^{-1} \mathrm{~min}^{-1}\right)$ & $\mathrm{q}_{\mathrm{e}}\left(\mathrm{mgg}^{-1}\right)$ & $\mathrm{R}^{2}$ \\
& 9.960 & 58.823 & 0.999 \\
\hline
\end{tabular}




\section{CONCLUSIONS}

$U$. dioica is essentially a lignocellulosic, non-toxic, cheap and easyto-access plant worldwide. In the present study, the use of $U$. dioica has been reported as adsorbent for the adsorption of MG. The improvement of dye adsorption was achieved through the use of statistical optimization of process parameters. Optimized conditions were found as $\mathrm{pH} 6.5,50{ }^{\circ} \mathrm{C}$ and the initial dye concentration of $200 \mathrm{mgL}^{-1}$. Despite being applied directly without any chemical pretreatment processes, $U$. dioica proved to be an effective adsorbent with up to $91.67 \%$ dye removal under the optimized conditions.

\section{EXPERIMENTAL SECTION}

\section{Preparation of materials}

$U$. dioica collected from Giresun in Black Sea Region was washed several times with deionized water and dried firstly at ambient temperature then at $80^{\circ} \mathrm{C}$ for $48 \mathrm{~h}$ in oven to remove the moisture. The samples were ground and passed through a $0.5 \mathrm{~mm}$ sieve. The adsorbent was stored in a dark bottle during the adsorption experiments.

The stock solution of malachite green (chemical formula $\mathrm{C}_{23} \mathrm{H}_{25} \mathrm{~N}_{2} . \mathrm{C}_{2} \mathrm{HO}_{4} \cdot 0.5 \mathrm{C}_{2} \mathrm{H}_{2} \mathrm{O}_{4}$, molecular weight: $463.50 \mathrm{gmol}^{-1}, \lambda_{\max }: 618 \mathrm{~nm}$ ) was prepared $1 \mathrm{gL}^{-1}$ with double distilled water using malachite green oxalate. The stock solution was diluted to prepare the desired concentrations. The $\mathrm{pH}$ of the solutions was adjusted with $\mathrm{HCl}(0.1 \mathrm{M})$ and $\mathrm{NaOH}(0.1 \mathrm{M})$. The chemicals were analytical grade and supplied from Sigma Aldrich.

\section{Adsorption studies}

The batch model was applied for adsorption studies. In the batch model, $50 \mathrm{~mL}$ of dye solution at various $\mathrm{pH}$ values and current amount of adsorbent were stirred at $200 \mathrm{rpm}$ at $25{ }^{\circ} \mathrm{C}$ for $2 \mathrm{~h}$, and then centrifuged at $3000 \mathrm{rpm}$ to separate the liquid phase. The dye concentrations were determined by UV-visible spectrophotometer (Mapada-UV6100PCS Double Beam Spectrophotometer) at $618 \mathrm{~nm}$. The adsorption studies were performed to determine the effects of parameters such as $\mathrm{pH}(2-8)$, initial dye concentration (30-200 mgL-1), adsorbent amount (0.05-0.3 g) and contact time (15-120 min) and temperature $\left(25-55^{\circ} \mathrm{C}\right)$. The effect of $\mathrm{pH}$ was studied the range of 2-8 that was adjusted using $0.1 \mathrm{M} \mathrm{HCl}$ and $0.1 \mathrm{M} \mathrm{NaOH}$. To determine the effect of contact time, $0.1 \mathrm{~g}$ adsorbent was added to a $150 \mathrm{ppm} \mathrm{MG}$ solution at the $\mathrm{pH}: 6$ 
for $15,30,45,60,75,90$ and 120 min. Adsorption isotherm was performed by shaking different initial dye concentration (30-200 mgL-1) with the fixed adsorbent amount $(0.1 \mathrm{~g})$ until equilibrium. Adsorption kinetics were determined by analyzing dye removal at different time intervals (15-120 min).

The percentage of dye adsorption and the amount of dye uptake at the equilibrium time were calculated using Eq. (3) and Eq. (4).

$$
\begin{aligned}
& \% \text { Dye Adsorption }=\frac{c_{0}-c_{e}}{c_{o}} \times 100 \\
& q_{e}=\frac{c_{0}-c_{e}}{W} \times V
\end{aligned}
$$

$\mathrm{c}_{0}$ : the initial dye concentration $\left(\mathrm{mgL}^{-1}\right), \mathrm{c}_{\mathrm{e}}$ : the equilibrium dye concentration $\left(\mathrm{mgL}^{-1}\right), \mathrm{q}_{\mathrm{e}}$ : the adsorbed dye per gram of adsorbent at equilibrium time $\left(\mathrm{mgg}^{-1}\right)$, $\mathrm{V}$ : the dye solution volume (L) and $\mathrm{W}$ : the adsorbent mass $(\mathrm{g})$. All experiments were carried out in triplicates and the results were used in data analysis.

\section{Adsorption isotherms}

Adsorption isotherms describe interactions between adsorbates and adsorbents. Isotherm models for the single component systems that express the adsorption isotherms mathematically are Langmuir, Freundlich, Redlich-Peterson, BET, Tempkin and Koble-Corrigan [34,35]. There are also multicomponent isotherm models derived from these single component system isotherms. Multicomponent isotherm models are also used for the adsorption of wastewater containing multiple pollutants $[31,36]$. The data obtained from these isotherm models provide important information about the adsorption mechanisms and the surface activities of the adsorbent.

The Langmuir isotherm model assumes that the surface is homogenous and covered by a monolayer of adsorbate. The linear Langmuir equation is as follows;

$$
\frac{1}{q_{e}}=\frac{1}{q_{\max }}+\left(\frac{1}{q_{\max K_{L}}}\right) \frac{1}{C_{e}}
$$

$\mathrm{C}_{\mathrm{e}}$ : equilibrium dye concentration $\left(\mathrm{mgL}^{-1}\right)$, $\mathrm{q}_{\mathrm{e}}$ : adsorption capacity at equilibrium $\left(\mathrm{mgg}^{-1}\right)$, $\mathrm{q}_{\max }$ : maximum adsorption capacity $\left(\mathrm{mgg}^{-1}\right)$ and $\mathrm{K}_{\mathrm{L}}$ : the Langmuir constant $\left(\mathrm{Lmg}^{-1}\right)$.

The $1 / q_{e}$ versus $1 / c_{e}$ give straight line. The value of $q_{\max }$ and $K_{L}$ were calculated from the slope and intercept of this plot [37] and are exhibited in Table 3. 
The Freundlich isotherm equation is as follows;

$$
\ln q_{e}=\ln K_{F}+\frac{1}{n} \ln c_{e}
$$

$\mathrm{K}_{\mathrm{F}}$ : the Freundlich constant, $\mathrm{n}$ : the heterogeneity factor related to the adsorption intensity $\left(\mathrm{mgL}^{-1}\right)$.

\section{Adsorption kinetics}

Two adsorption kinetic models, pseudo-first order and second-order models have been carried out to explain the adsorption kinetics.

The Lagergren pseudo-first order rate expression can be given as;

$$
\ln \left(q_{e}-q_{t}\right)=\ln q_{e}-k_{1} t
$$

$\mathrm{q}_{\mathrm{e}}$ and $\mathrm{q}_{\mathrm{t}}$ the amount of dye uptake at equilibrium and at time $\mathrm{t}\left(\mathrm{mgg}^{-1}\right)$, respectively, and $\mathrm{k}_{1}$ : rate constant of adsorption $\left(\mathrm{min}^{-1}\right)$. It is calculated $k_{1}$ (slope) and intercepts $\left(\operatorname{lnq} q_{e}\right)$ from the linear plots of $\ln \left(q_{e}-q_{t}\right)$ versus $t$.

The pseudo-second order kinetic model is shown in Eq. 8. $\mathrm{k}_{2:}$ the rate constant of adsorption $\left(\mathrm{gmg}^{-1} \mathrm{~min}^{-1}\right), \mathrm{q}_{\mathrm{e}}$ and $\mathrm{q}_{\mathrm{t}}$ : the amount of dye uptake $\left(\mathrm{mgg}^{-1}\right)$ at equilibrium and at time $t\left(\mathrm{mgg}^{-1}\right)$, respectively. $\mathrm{k}_{2}$ and $\mathrm{q}_{\text {cale }}$ were calculated from the intercepts $\left(1 / \mathrm{k}_{2} \mathrm{q}^{2} \mathrm{e}\right)$ and slopes $\left(1 / \mathrm{q}_{\mathrm{e}}\right)$ of the plots of $\mathrm{t} / \mathrm{qt}$ vs. $t$ [31], respectively, and are presented in Table 4.

$$
\frac{1}{q_{t}}=\frac{1}{k_{2} q_{e}^{2}}+\frac{t}{q_{e}}
$$

\section{Optimization of adsorption conditions by RSM}

Design of experiments

The outcomes of the experiments conducted to reveal the impacts of temperature, $\mathrm{pH}$ and initial dye concentration on MG adsorption yields of $U$. dioica were given in Table 5 . These parameters were analyzed at 3 levels [-1 (low), 0 (medium), +1 (high)] for the optimization of adsorption yield. The limits of these independent variables were $25-55^{\circ} \mathrm{C}$ for temperature, $2-8$ for $\mathrm{pH}$ and $40-200 \mathrm{mgL}^{-1}$ for initial dye concentration. Adsorption assays were performed in $100 \mathrm{~mL}$ Erlenmeyer flasks containing $50 \mathrm{~mL}$ of dye solution. The statistical and graphical software Minitab $®$ Version 17 (State College, PA) was utilized for the experimental design and analysis of RSM. 
AN ALTERNATIVE USAGE OF URTICA DIOICA AS ADSORBENT FOR MALACHITE GREEN:

OPTIMIZATION STUDY

In regression analysis, the confidence level is $95 \%$ and significance level alpha ( $\alpha$ ) is considered as 0.05 . A $p$ (probability) value less than $\alpha$ (typically $\leq 0.05$ ) is regarded as statistically significant.

Table 5. BBD of parameters (temperature, $\mathrm{pH}$, and initial dye concentration) and experimental responses (adsorption) using RSM

\begin{tabular}{|c|c|c|c|c|}
\hline Run & \multicolumn{3}{|c|}{ Variables } & \multirow{2}{*}{$\begin{array}{c}\text { Response } \\
Y(\text { Adsorption, \%) }\end{array}$} \\
\hline & A (Temperature, $\left.{ }^{\circ} \mathrm{C}\right)$ & $\mathrm{B}(\mathrm{pH})$ & C (Dye, $\mathrm{mgL}^{-1}$ ) & \\
\hline 1 & 55 & 5 & 40 & 75.66 \\
\hline 2 & 25 & 5 & 40 & 66.63 \\
\hline 3 & 40 & 2 & 40 & 22.00 \\
\hline 4 & 25 & 8 & 120 & 81.68 \\
\hline 5 & 40 & 5 & 120 & 82.96 \\
\hline 6 & 55 & 5 & 200 & 90.07 \\
\hline 7 & 25 & 5 & 40 & 75.46 \\
\hline 8 & 25 & 5 & 200 & 82.71 \\
\hline 9 & 40 & 5 & 120 & 84.46 \\
\hline 10 & 40 & 2 & 200 & 18.83 \\
\hline 11 & 25 & 5 & 200 & 79.76 \\
\hline 12 & 55 & 5 & 40 & 77.86 \\
\hline 13 & 55 & 8 & 120 & 82.60 \\
\hline 14 & 40 & 5 & 120 & 83.11 \\
\hline 15 & 55 & 2 & 120 & 26.55 \\
\hline 16 & 40 & 8 & 40 & 63.08 \\
\hline 17 & 55 & 5 & 200 & 89.47 \\
\hline 18 & 25 & 2 & 120 & 26.80 \\
\hline 19 & 40 & 8 & 40 & 63.08 \\
\hline 20 & 40 & 5 & 120 & 82.96 \\
\hline 21 & 40 & 2 & 200 & 29.30 \\
\hline 22 & 25 & 8 & 120 & 74.08 \\
\hline 23 & 40 & 5 & 120 & 84.99 \\
\hline 24 & 25 & 2 & 120 & 23.02 \\
\hline 25 & 40 & 8 & 200 & 83.33 \\
\hline 26 & 40 & 5 & 120 & 85.06 \\
\hline 27 & 40 & 8 & 200 & 85.59 \\
\hline 28 & 55 & 2 & 120 & 30.00 \\
\hline 29 & 55 & 8 & 120 & 83.43 \\
\hline 30 & 40 & 2 & 40 & 21.25 \\
\hline
\end{tabular}




\section{ACKNOWLEDGMENTS}

This research was funded by Scientific Research Project of Giresun University (grant number FEN-BAP-A-160317-52).

\section{REFERENCES}

1. V.K. Garg; R. Kumar; R. Gupta; Dyes Pigm., 2004, 62, 1-10.

2. N. Gupta; A.K. Kushwaha; M.C. Chattopadhyaya; J. Chem. Pharm. Res., 2011, 3, 284-296.

3. A. Raducan; A. Olteanu; M. Puiu; D. Oancea; Cent. Eur. J. Chem., 2008, 6, 89-92.

4. E. Sudova; J. Machova; Z. Svobodova; Vet. Med., 2007, 52, 527-539.

5. U.U. Tezcan; F. Ates; N. Erginel; O. Ozcan; E. Oduncu; J. Environ. Manag., 2015, 15, 89-96.

6. D.J. Alderman; R.S. Clifton-Hadley; J. Fish Dis., 1993, 16, 297-311.

7. A.S. Sartape; A.M. Mandhare; V.V. Jadhav; P.D. Raut; M.A. Anuse; S. S. Kolekar; Arab. J. Chem., 2017, 10, 3229-3238.

8. W.C. Andersen; S.B. Turnipseed; J.E. Roybal; J. Agric. Food Chem., 2006, 54, 4517-4523.

9. M. Dastkhoon; M. Ghaedi; A. Asfaram; MH.A. Azqhandi; M.K.A. Purkait; Chem. Eng. Res. Des., 2017, 124, 222-237.

10. S. Ben-Ali; I. Jaouali; S. Souissi-Najar; A. Ouederni; J. Clean. Prod., 2017, 142, 3809-3821.

11. V.K. Gupta; C.K. Jain; S. Chandra; S. Agarwal; Water Res., 2002, 36, $2483-$ 2490.

12. S.M. Bowman; S.J. Free; Bioassays, 2006, 28, 799-808.

13. MR. Fathi; A. Asfaram; A. Farhangi; Spectrochim Acta A Mol Biomol. Spectrosc., 2015, 135, 364-372.

14. I.A.V. Tan; B.H. Hameed; A.L. Ahmad; Chem. Eng. J., 2007, 127, 111-119.

15. A. Mittal; L. Krishnan; V.K. Gupta; Sep. Purif. Technol., 2005, 43, 125-133.

16. R. Gong; K. Zhong; Y. Hu; J. Chen; G. Zhu; J. Environ. Manage., 2008, 88, 875-880.

17. R. Jain; M. Mathur; S. Sikarwar; A. Mittal; J. Environ. Manage., 2006, 85, 956-964.

18. A.S. Ozcan; S. Tetik; A. Ozcan; Sep. Sci. Technol., 2004, 39, 301-320.

19. T. Baytop; Therapy with Plant in Turkey, Istanbul University, Faculty of Pharmacy (2nd press), Nobel Medicine Bookstores; Istanbul, Turkey, 1989.

20. K.K. Mueen Ahmed; S. Parsuraman; Sys. Rev. Pharm., 2014, 5, 6-8.

21. I. Gülçin; O.I. Küfrevioglu; M. Oktay; M. E. Büyükokuoglu; J. Ethnopharmacol., 2004, 90, 205-215.

22. J. Viktorova; Z. Jandova; M. Madlenakova; P. Prouzova; V. Bartunek; B. Vrchotova; P. Lovecka; L. Musilova; T. Macek; Plos One, 2016, 12, 1-12.

23. S. Hoşbaş; M. Aslan; E. Sezik; Turk. J. Pharm. Sci., 2014, 11, 223-230. 
24. N. Di Virgilioa; E.G. Papazogloub; Z. Jankauskienec; S. Di Lonardod; M. Praczyke; K. Wielgusze; Ind. Crops Prod., 2015, 68, 42-49.

25. V.D. Dimitrijević; M.N. Stanković; D.M. Đorđević; I.M. Krstić; M.G. Nikoli;, A. L.J. Bojić; N. S. Krstić; Studia UBB Chemia, 2019, 1, 19-39

26. G.E.P. Box; D.W. Behnken; Technometrics, 1960, 2, 455-475.

27. S. Gurkok; D. Cekmecelioglu; Z.B. Ogel; Bioresour. Technol., 2011, 102, 49254929.

28. M. Ozdal; S. Gurkok; O.G. Ozdal; 3 Biotech., 2017, 7, 117.

29. Y. Sağ; T. Kutsal; Process Biochem., 1997, 32, 591-597.

30. B. Ertan; D. Efe; D; Adsorption properties of U. dioica on colour removal of Malachite Green, In:1 st international technological sciences and design symposium, Giresun, Turkey, 27-29 June 2018, pp. 107-115.

31. D.O. Hayward; B.M.W. Trapnell; W. Garden; Chemisorption, Butterworths, London, 1964, pp. 67-159.

32. S. Lagergren; Zurtheorie der sogenannten adsorption gelosterstoffe, Kungliga Svenska Vetenskaps akademiens, Handlingar, 1898, pp. 1-39.

33. Y.S. Ho; G. McKay; Process Saf. Environ. Prot., 1998, 76, 183-191.

34. H.M.F. Freundlich; Uber die adsorption in Losungen. In: Zeitschrift fur Physikalische Chemie, Leipzig, 1906, pp. 385-470.

35. I. Langmuir; J. Am. Chem. Soc., 1918, 40, 1361-1403.

36. Y. Tian; C. Ji; M. Zhao; Chem. Eng. J., 2010, 165, 474-481.

37. Z. Aksu; H. Gülen; Process Biochem., 2002, 38, 161-173. 
